\title{
Ameliorative effects of konjac glucomannan on human faecal $\beta$-glucuronidase activity, secondary bile acid levels and faecal water toxicity towards Caco-2 cells
}

\author{
Wen-Tzu Wu ${ }^{1}$, Han-Chung Cheng ${ }^{1}$ and Hsiao-Ling Chen ${ }^{1,2_{*}}$ \\ ${ }^{1}$ School of Nutrition, Chung Shan Medical University, No. 110, Section 1, Jianguo North Road, Taichung City 402, \\ Taiwan, $R O C$ \\ ${ }^{2}$ Department of Nutrition, Chung Shan Medical University Hospital, Taichung, Taiwan, ROC
}

(Received 3 February 2010 - Revised 30 August 2010 - Accepted 1 September 2010 - First published online 10 December 2010)

\section{Abstract}

Konjac glucomannan (KGM) has been shown to increase human colon microbial ecology and reduce faecal toxicity in mice. The main goal of the present study was to assess the effects of a KGM supplement into a low-fibre diet on precancerous markers of colon cancer in a double-blind, placebo- and diet-controlled study. Adult volunteers consumed defined diets supplemented with konjac ( $4 \cdot 5 \mathrm{~g} / \mathrm{d}$ ) or placebo (maize starch) for 4 weeks. Stools collected before and at the end of the supplementation were analysed for $\beta$-glucosidase, $\beta$-galactosidase and $\beta$-glucuronidase activities, microflora and bile acids. Faecal water was co-incubated with Caco- 2 cells, a model of human colonocytes, to determine the cytotoxicity and DNA-damaging effect as assessed by the comet assay. The results indicated that the KGM supplement significantly decreased faecal $\beta$-glucuronidase activity by 25.6 ( $\mathrm{se} 7 \cdot 8$ ) \% and faecal secondary bile acid level by 42.4 (SE 11.8 ) \%. In contrast, consuming the defined diet supplemented with placebo for 4 weeks did not improve these determinants. The KGM-supplemented diet, but not the placebo diet, significantly increased the survival rate (\%) of Caco- 2 cells co-incubated with faecal water for 1 and $3 \mathrm{~h}$, respectively. In addition, KGM significantly reduced the DNA damage induced by the faecal water alone or in combination with $\mathrm{H}_{2} \mathrm{O}_{2}$. The faecal bifidobacteria and lactobacilli levels increased only with the KGM-supplemented diet. Therefore, we conclude that supplementation of KGM into a low-fibre diet improved the faecal microbial ecology and metabolites, which may contribute to the reduced toxicity of faecal water and precancerous risk factors of human colon cancer.

Key words: Konjac glucomannan: $\beta$-Glucuronidase: Bile acids: DNA damage: Cytotoxicity

Colorectal cancer is the third leading cause of cancer mortality in the USA ${ }^{(1)}$. Dietary fibre, the food component that is metabolised mainly in the caecum and colon, has been considered a modulator for incidence of colorectal cancer. However, the results from epidemiological studies have been inconsistent ${ }^{(2)}$. It has been concluded that an increased intake of food containing dietary fibre is associated with a decreased risk of colorectal cancer ${ }^{(2)}$. However, the precise mechanisms for the probable protective role of dietary fibre remain unclear. It has been proposed that dietary fibres dilute faecal toxin content, decrease transit time and increase stool weights ${ }^{(2)}$, all of which decrease the exposure of colonocytes to mutagens. However, it is generally thought that viscous soluble dietary fibres adsorb bile acids and therefore enhance their faecal excretion $^{(3)}$. It is important to clarify the modulatory role of soluble fibres on the faecal secondary bile acid level since it exerts adverse effects on epithelial barrier function and is thought to be related to tumour promotion ${ }^{(4,5)}$.

Another modulatory role of soluble dietary fibre in faecal mutagen load that needs further study is the bacteria enzymes that hydrolyse pro-carcinogenic glycosides into carcinogenic aglycosides ${ }^{(6)}$. Therefore, soluble dietary fibres may reduce the risk of colorectal cancer partially by reducing faecal carcinogen formation that is modulated by the colonic bacteria profile. Secondly, SCFA, especially butyrate, derived from fermentation of dietary fibres, are shown to increase apoptosis and suppress the growth of colon cancer cells ${ }^{(7,8)}$. Another means for dietary fibres to promote colon health is by increasing the population of probiotics such as bifidobacteria ${ }^{(9)}$.

Konjac glucomannan (KGM), derived from the tuber of Amorphophallus konjac C. Koch from the botanical family Araceae, is a well-known soluble dietary fibre

Abbreviations: HBSS, Hanks balanced salt solution; KGM, konjac glucomannan. 
consumed in Taiwan, Japan and China. KGM is a $\beta-(1 \rightarrow 4)$ linked polysaccharide composed of a D-glucosyl and D-mannosyl backbone that is lightly branched, possibly through $\beta-(1 \rightarrow 6)$ glucosyl units ${ }^{(10)}$. The addition of KGM to a low-fibre diet has been shown to normalise bowel movement in constipated children ${ }^{(11)}$ and adults ${ }^{(12)}$ and to increase faecal weights and SCFA production ${ }^{(12,13)}$, which suggest a protective role of KGM in the colon. In addition, several studies have demonstrated that supplementation of KGM into a fibre-free feed in mice reduced faecal waterinduced cytotoxicity and DNA damage effects in Caco-2 cell lines, a model for colonic epithelium cells ${ }^{(14,15)}$. These findings suggest that KGM supplementation can reduce the toxicity of colonic content in humans, and subsequently may exert chemopreventive function for colorectal cancer. However, the roles of KGM in humans on colonic bacterial activity, faecal secondary bile acid levels and faecal water toxicity have never been clarified.

A $10 \%$ KGM feed has been shown to reduce the incidence of dimethylhydrazine-induced colon tumours in rats $^{(16)}$. However, this result may not be applicable to humans since the amount of fibre administered to animals is greater than the amount that human subjects could routinely consume. In order to determine the protective effects of KGM on colon cancer risk, the present study determined the effects of a KGM supplement in adults on faecal toxicity towards Caco-2 cells and potential pre-neoplastic risk factors of colorectal cancer, such as faecal toxin-producing enzyme activities and bile acids, in a double-blind, placebo-controlled and diet-controlled trial.

\section{Methods}

\section{Subjects}

Adult volunteers were recruited via advertisements in communities near to Chung Shan Medical University (Taichung City, Taiwan). We recruited healthy adults who passed bowel movement more than three times a week, with normal serum cholesterol concentration $(<2400 \mathrm{mg} / \mathrm{l})$, and were willing to comply with the experimental protocol and defined meals. The criteria for exclusion were selfreported lactose intolerance, non-omnivorous diet, habitual consumption of probiotic food and any perception of chronic bowel irregularity. The recruited volunteers were stratified by sex and then were randomly divided into a placebo or KGM group. Each group consisted of one male and fourteen female adults. The mean age was $41 \cdot 2$ ( $\mathrm{SE} 3.6)$ and 40.0 ( $\mathrm{SE} 3.4$ ) years, respectively, while the BMI was 23.5 (SE 1.0$)$ and $23.9(\operatorname{SE~} 1.0) \mathrm{kg} / \mathrm{m}^{2}$, respectively, for the volunteers in the placebo and KGM group.

\section{Experimental design}

Before the experimental period, the volunteers were instructed to record their $3 \mathrm{~d}$ food intake in order to assess their energy intake from which the investigators designed their experimental diet. Nutrient analysis was done using local nutrient composition tables ${ }^{(17)}$. The double-blind, placebo-controlled, diet-controlled study consisted of a 4-week placebo or glucomannan (KGM) period. The volunteers consumed $7 \mathrm{~d}$ cycle menus of a typical low-fibre Taiwanese diet as described in a previous study ${ }^{(13)}$ that met their energy requirement with a typical nutrient pattern of the adult population in Taiwan ${ }^{(18)}$. The volunteers consumed the meals in the experimental unit and were not allowed to consume additional food. The exact energy and nutrient intake during the experiment were determined by subtracting the leftovers from the offered meal. KGM or placebo was taken as capsules $(0.5 \mathrm{~g} /$ capsule) during each meal with $0.5-1.0 \mathrm{~g}$ (one to two capsules) during days $1-7$ to prevent potential bowel complication. During the rest of the study, the dose was maintained at $1.5 \mathrm{~g}$ (three capsules) per meal, $4.5 \mathrm{~g} / \mathrm{d}$, which has been shown effective to promote faecal bifidobacteria growth in human subjects ${ }^{(12,13)}$. The present study was conducted according to the guidelines laid down in the Declaration of Helsinki, and all procedures involving human subjects were approved by the Medical Ethics Committee of the Chung Shan Medical University Hospital. A written informed consent was obtained from all the subjects.

\section{Faecal collection}

The volunteers each collected voided faeces during the week before and during days 21-28 of the study. The samples were stored in ice buckets and immediately sent to our laboratory. Aliquots (approximately 10\%, w/w) of each faeces were homogenised with twofold of deionised water in a blender and were stored at $-20^{\circ} \mathrm{C}$ until they were lyophilised. The lyophilised faeces from an individual were pooled together to be a faecal composite and stored at $-20^{\circ} \mathrm{C}$ for further analysis.

\section{Faecal bacteria enzyme activity}

The $\beta$-glucosidase, $\beta$-galactosidase and $\beta$-glucuronidase activities were measured from the release of 2 -nitrophenol from synthetic substrate, $p$-nitrophenyl- $\beta$-D-glucopyranoside, $p$-nitrophenyl- $\beta$-D-galactopyranoside and 4-nitrophenyl- $\beta$-D-glucuronide, respectively, as described by Marteau et $a l .{ }^{(19)}$. An aliquot $(0.5 \mathrm{~g})$ of dry faecal composite was sonicated in $15 \mathrm{ml}$ buffer $\left(0 \cdot 1 \mathrm{M}-\mathrm{Na}_{2} \mathrm{HPO}_{4}, 0 \cdot 15 \mathrm{M}-\mathrm{NaCl}\right.$, $\mathrm{pH} 7 \cdot 4)$ in an ice bath for $1 \mathrm{~min}$, followed by centrifugation at $10000 \mathrm{~g}, 4^{\circ} \mathrm{C}$ for $10 \mathrm{~min}$. An aliquot $(0.5 \mathrm{ml})$ of supernatant was mixed with $0.25 \mathrm{ml}$ of substrate $(52 \mathrm{~mm})$ at $37^{\circ} \mathrm{C}$ for 2,5 and $10 \mathrm{~min}$, respectively, from which the initial reaction rate was determined. The reaction product was measured at $405 \mathrm{~nm}$. The protein contents in the samples were analysed using a protein assay reagent 
(Life Science Research, Hercules, CA, USA). The enzyme activity was expressed as $\mu \mathrm{mol} / \mathrm{min}$ per mg protein.

\section{Faecal water preparation}

Faecal water represents the portion of colonic content that directly contacts the colonic epithelium cells and is a good tool to assess the role of dietary intervention in colon carcinogenesis $^{(20)}$. Faecal water was prepared with the method described by Rieger et al. ${ }^{(20)}$, with slight modification. The lyophilised faecal composites were rehydrated to threefold their original faecal wet weight, followed by centrifugation at $36000 \mathrm{~g}, 4^{\circ} \mathrm{C}$ for $2 \mathrm{~h}$. The supernatant fluid, i.e. faecal water, was used immediately for incubation with the Caco- 2 cells. The remaining faecal water was stored in $-20^{\circ} \mathrm{C}$ for bile acids analysis.

\section{Analysis of bile acids in faecal water}

A $50 \mu \mathrm{g}$ hyodeoxycholic acid (Sigma Chemical Company, St Louis, MO, USA) was added to $0.5 \mathrm{ml}$ faecal water as an internal standard. After a $1 \mathrm{~h}$ mild alkaline hydrolysis with $1 \mathrm{ml} 5 \mathrm{M}-\mathrm{NaOH}$ at $90^{\circ} \mathrm{C}$, bile acids were extracted and derivatised as the method described by Czubayko et al. ${ }^{(21)}$. The samples were dissolved in $0.5 \mathrm{ml}$ of cyclohexane before they were injected onto a gas chromatograph (GC14B; Shimadzu Corporation, Tokyo, Japan) fitted with a fused silica column (HP-5, 0.25 mm $\times 0.25 \mu \mathrm{m} \times 60 \mathrm{~m}$; Agilent Technologies, Inc., Santa Clara, CA, USA), an automatic on-column injection system (AOC-20; Shimadzu Corporation) and a flame ionisation detector. The injector and detector temperature was 300 and $320^{\circ} \mathrm{C}$, respectively, and the initial oven temperature was $150^{\circ} \mathrm{C}$ for $3 \mathrm{~min}$, increasing to $270^{\circ} \mathrm{C}$ at $30^{\circ} \mathrm{C} / \mathrm{min}$ increment and then maintained at $270^{\circ} \mathrm{C}$ for $64 \mathrm{~min}$. The flow rate of the carrier, $\mathrm{N}_{2}$, was $2 \mathrm{ml} / \mathrm{min}$. Peak areas were analysed with a C-R6A Chromatopac (Shimadzu Corporation). Data are expressed as faecal bile acid content:

\section{Wet faeces $(\mu \mathrm{mol} / \mathrm{g})$}

$$
\begin{gathered}
=\text { concentration in faecal water }(\mu \mathrm{mol} / \mathrm{ml}) \\
\times \text { faecal water ratio }(\mathrm{ml} / \mathrm{g} \text { wet faeces })
\end{gathered}
$$

\section{Quantification of faecal microflora}

The changes in faecal bacteria population were assessed using the fluorescence in situ hybridisation method as described previously ${ }^{(12,13)}$. The genotypic probes targeting $16 \mathrm{~S}$ rRNA of bacteria were Bif164, Laa1, Bac303 and Ncib10748, specific for bifidobacteria ${ }^{(22)}$, lactobacilli ${ }^{(23)}$, bacteroides $^{(24)}$ and clostridia ${ }^{(25)}$, respectively. The nucleic acid stain 4'-6-diamidino-2-phenylindole solution was used for total bacterial counts ${ }^{(12,13)}$. Probe fluorescence was detected with a Zeiss Axioskop2 microscope
(Carl Zeiss, Jena, Germany) fitted for epifluorescence microscope with a $100 \mathrm{~W}$ mercury bulb (HBO 103), a $20 \times$ Plan-neofluar objective, a filter set 01,09 and 20, and a cooled charge-coupled device video camera (MacroFire, Model S99831; Optronics, Goleta, CA, USA). The bacteria concentrations are expressed as $\log _{10}$ counts/g wet faeces. The proportion of specific bacteria (\% total bacteria) is calculated as the faecal concentration (counts/g faeces) of this genus of bacteria quantified by specific probe divided by that of all bacteria quantified by 4'-6-diamidino-2-phenylindole.

\section{Cell culture}

Caco-2 cells were used as a model of colonocytes to assess the role of the supplement on cytotoxicity and DNA-damaging effect of faecal water as described previously $^{(14,15)}$. The Caco-2 cells were obtained from the Bioresource Collection and Research Center (Hsinchu, Taiwan, ROC) and were cultured as described previously $^{(14,15)}$. The cells were harvested at approximately 90\% confluence and re-suspended in Hank's balanced salt solution (HBSS) at a concentration of $2 \times 10^{6}$ cells $/ \mathrm{ml}$ for further analysis of cytotoxicity and for the comet assay.

\section{Viability of Caco-2 cells with faecal water}

Cytotoxicity of faecal water towards Caco-2 cells was determined for each volunteer in triplicate. The cell suspension ( $450 \mu \mathrm{l}, 2 \times 10^{6}$ cells/ml HBSS) was incubated with $50 \mu \mathrm{l}$ HBSS as control or faecal water at $37^{\circ} \mathrm{C}$ for 1 or $3 \mathrm{~h}$ in a gently shaking water-bath ${ }^{(14)}$. The cell survival rate (\% to initial cell number) was determined by trypan blue exclusion staining.

\section{Comet assay}

The DNA-damaging effect of faecal water was determined individually by the comet assay, as described previously $^{(14,15,20)}$. Briefly, the Caco-2 cell suspension ( $450 \mu \mathrm{l}, 2 \times 10^{6}$ cells/ml HBSS) was incubated with $50 \mu \mathrm{l}$ of HBSS as control or faecal water for $3 \mathrm{~h}$, followed by centrifugation at $850 \mathrm{~g}$. The harvested cells were re-suspended in low-melting-point agarose (in PBS) and were then placed between two layers of normal melting-point agarose on frosted glass microscope slides. Another set of slides was further treated with $75 \mu \mathrm{M}-\mathrm{H}_{2} \mathrm{O}_{2}$ for $5 \mathrm{~min}$ on ice. The slides were subjected to electrophoresis $(300 \mathrm{~mA}$ at $25 \mathrm{~V}$ for $25 \mathrm{~min}$ ) after the cells were lysed and DNA was unwinded. The slides were stained with ethidium bromide for analysis of the comet images using a fluorescence microscope (Olympus/BX51; Center Valley, PA, USA) equipped with the Interactive Image Analysis Comet Assay III (Perceptive Instrument; Haverhill, Suffolk, UK). The DNA strand breaks were expressed as tail moment. Each value presented was calculated from three batches 
of experiments, each of which included two slides with at least 200 random comets.

\section{Statistical analyses}

The data were analysed using Statistical Package for Social Sciences version 10.0 (SPSS, Inc., Chicago, IL, USA) and presented as mean values with their standard errors. The concentrations of faecal bacteria were log transformed before analysis. Differences that occurred after 4 weeks of dietary interventions were analysed using paired Student's $t$ tests. The relative change (\% difference before and at the end of intervention) was compared by the unpaired Student's $t$ test. The differences were considered significant at $P<0.05$.

\section{Results}

Faecal $\beta$-glucosidase, $\beta$-galactosidase and $\beta$-glucuronidase activities

Faecal $\beta$-glucosidase, $\beta$-galactosidase and $\beta$-glucuronidase activities did not significantly change with the placebosupplemented diet (placebo diet) (Table 1). The KGMsupplemented diet did not modulate faecal $\beta$-galactosidase activity. However, the KGM diet significantly increased faecal $\beta$-glucosidase activity by 10.5 (SE 5.9) \% ( $P=0.012)$ and decreased faecal $\beta$-glucuronidase activity by 31.5 (SE $7 \cdot 2) \%(P=0 \cdot 008)$. The relative change in $\beta$-glucuronidase activity $(\%)$ caused by the placebo and KGM was significantly different $(P=0 \cdot 001)$.

\section{Faecal bile acids}

Consuming the placebo diet did not significantly change the level of any bile acid in the faecal water (Table 2). However, on the one hand, the KGM diet significantly decreased the concentration of total secondary bile acids, sum of deoxycholic acid, lithocholic acid and ursodeoxycholic acid, from 1.56 (SE 0.41 ) to 0.88 (SE 0.20) $\mu \mathrm{mol} / \mathrm{g}$ wet faeces $(P<0 \cdot 001)$. The lithocholic acid level alone was significantly decreased by $13 \cdot 18($ SE $0 \cdot 3) \%(P=0 \cdot 041)$ with the KGM diet. On the other hand, the KGM diet significantly increased the concentration of total primary bile acids, sum of cholic acid and chenodeoxycholic acid from 0.67 (sE 0.14 ) to 0.97 (sE 0.18 ) $\mu \mathrm{mol} / \mathrm{g}$ wet faeces $(P<0.001)$ and the chenodeoxycholic acid alone was significantly increased by 53.9 (SE 14.9) \%. The proportion of secondary bile acids to total bile acids was 66.7 (se 3.3) \% in the beginning of the KGM period, which was significantly decreased to $47 \cdot 4$ (SE 4.7 ) \% with the KGM diet. In contrast, the relative proportion of secondary bile acid did not change after 4 weeks of the placebo diet.

\section{Human faecal water-induced cell death of Caco-2 cells}

The cell survival rate (\% to original number) with 1 and $3 \mathrm{~h}$ treatment of control medium was $95 \cdot 2$ (SE 0.7) and $91 \cdot 2$ (SE $0 \cdot 8) \%$, respectively, which were reduced as treated with faecal water from either group of volunteers. Consuming the placebo diet for 4 weeks did not alter the survival rate of the Caco- 2 cells co-incubated with $1 \mathrm{~h}, 90 \cdot 2$ (SE 0.8$) \%$ at week $0 v .89 \cdot 3(\operatorname{se~} 1 \cdot 1) \%$ at week 4 , or $3 \mathrm{~h}$ faecal water, $83.4(\operatorname{se} 0.7) \%$ at week $0 v .82 .7$ (SE 0.6) \% at week 4 . In contrast, consuming the KGM diet significantly increased the survival rate of Caco-2 cells co-incubated with either $1 \mathrm{~h}, 87.5$ (SE $0.9 \%)$ at week $0 v .90 \cdot 9$ (SE 0.7$) \%$ at week $4(P=0 \cdot 001)$, or $3 \mathrm{~h}$ faecal water, $81 \cdot 1$ (SE $0 \cdot 8) \%$ at week $0 v .84 .3(\operatorname{se~} 0 \cdot 9) \%$ at week $4(P=0 \cdot 001)$.

\section{Human faecal water-induced DNA damage in Caco-2 cells}

Consuming the placebo diet for 4 weeks significantly increased the faecal water-induced DNA damage (denoted as tail moment) of Caco- 2 cells (week $0 \quad v$. week 4 , $P<0.05)$, implying that the placebo diet increased the DNA-damaging effect of faecal water (Table 3). In contrast, the KGM diet significantly decreased the DNA damage induced by the faecal water (week $0 v v$. week 4 , $P<0 \cdot 001)$. The KGM diet further significantly reduced the tail moment of the Caco-2 cells treated with faecal water in combination with $\mathrm{H}_{2} \mathrm{O}_{2}$ from 54.0 (SE 0.7 ) to 44.9 ( $\mathrm{SE}$ 0.8) (week $0 v$. week $4, P<0 \cdot 001$ ).

Table 1. Faecal bacteria enzyme activities in adult volunteers supplemented with 4 weeks of placebo or konjac glucomannan (Mean values with their standard errors, $n$ 15)

\begin{tabular}{|c|c|c|c|c|c|c|c|c|c|c|c|c|}
\hline & \multicolumn{6}{|c|}{ Placebo } & \multicolumn{6}{|c|}{ Konjac glucomannan } \\
\hline & \multicolumn{2}{|c|}{ Week 0} & \multicolumn{2}{|c|}{ Week 4} & \multicolumn{2}{|c|}{ Change†‡ (\%) } & \multicolumn{2}{|c|}{ Week 0} & \multicolumn{2}{|c|}{ Week 4} & \multicolumn{2}{|c|}{ Change (\%) } \\
\hline & Mean & SE & Mean & SE & Mean & SE & Mean & SE & Mean & SE & Mean & SE \\
\hline \multicolumn{13}{|c|}{ Faecal enzymes ( $\mu \mathrm{mol} / \mathrm{min}$ per $\mathrm{mg}$ protein) } \\
\hline$\beta$-Glucosidase & $7 \cdot 8$ & $1 \cdot 1$ & $8 \cdot 8$ & $1 \cdot 0$ & 11.5 & $8 \cdot 4$ & $9 \cdot 7$ & 0.9 & $11 \cdot 8^{*}$ & $1 \cdot 2$ & $10 \cdot 5$ & $5 \cdot 9$ \\
\hline$\beta$-Galactosidase & $10 \cdot 1$ & 1.6 & 11.6 & 1.7 & $13 \cdot 8$ & 7.0 & 13.7 & 1.3 & $13 \cdot 7$ & 1.2 & $3 \cdot 7$ & $5 \cdot 0$ \\
\hline$\beta$-Glucuronidase & 5.5 & 0.8 & $6 \cdot 3$ & 1.0 & $19 \cdot 9$ & $10 \cdot 8$ & 7.5 & 0.9 & $5 \cdot 3^{\star \star}$ & 0.8 & $-31 \cdot 5^{\star \star}$ & $7 \cdot 2$ \\
\hline
\end{tabular}

Mean values were significantly different between week 4 and week 0 within a group (as analysed by paired Student's $t$ test): ${ }^{\star} P<0.05$, ${ }^{\star \star} P<0.01$.

† Change $(\%)=($ enzyme activity $(\mu \mathrm{mol} / \mathrm{min}$ per $\mathrm{mg}$ protein) at week $4-$ enzyme activity at week 0$) /$ enzyme activity at week 0 .

$\ddagger$ Mean values were significantly different between placebo and KGM groups $(P<0.01$; Student's $t$ test). 
Table 2. Faecal bile acid profile in adult volunteers supplemented with 4 weeks of placebo or konjac glucomannan

(Mean values with their standard errors, $n$ 15)

\begin{tabular}{|c|c|c|c|c|c|c|c|c|}
\hline & \multicolumn{8}{|c|}{ Wet faeces $(\mu \mathrm{mol} / \mathrm{g})$} \\
\hline & \multicolumn{4}{|c|}{ Placebo } & \multicolumn{4}{|c|}{ Konjac glucomannan } \\
\hline & \multicolumn{2}{|c|}{ Week 0} & \multicolumn{2}{|c|}{ Week 4} & \multicolumn{2}{|c|}{ Week 0} & \multicolumn{2}{|c|}{ Week 4} \\
\hline & Mean & SE & Mean & SE & Mean & SE & Mean & SE \\
\hline \multicolumn{9}{|l|}{ Primary bile acids } \\
\hline Cholic acid & 0.27 & 0.07 & 0.23 & 0.05 & 0.25 & 0.05 & 0.27 & 0.07 \\
\hline Chenodeoxycholic acid & 0.52 & $0 \cdot 11$ & 0.40 & 0.13 & 0.42 & $0 \cdot 11$ & $0 \cdot 70^{\star *}$ & $0 \cdot 13$ \\
\hline \multicolumn{9}{|l|}{ Secondary bile acids } \\
\hline Deoxycholic acid & 0.92 & 0.20 & 0.82 & $0 \cdot 13$ & 1.07 & $0 \cdot 16$ & 0.61 & $0 \cdot 16$ \\
\hline Lithocholic acid & 0.47 & 0.15 & 0.56 & 0.17 & 0.28 & 0.08 & $0.15^{\star}$ & 0.04 \\
\hline Ursodeoxycholic acid & 0.12 & 0.02 & 0.16 & 0.03 & 0.21 & 0.05 & 0.12 & 0.07 \\
\hline Total bile acids & $2 \cdot 30$ & 0.36 & $2 \cdot 17$ & 0.34 & $2 \cdot 23$ & 0.52 & $1 \cdot 84$ & 0.31 \\
\hline
\end{tabular}

Mean values were significantly different between week 4 and week 0 within a group (as analysed by paired Student's $t$ test): ${ }^{\star} P<0.05,{ }^{\star \star} P<0.01$

\section{Faecal microflora}

The placebo diet did not modulate the faecal concentration of any genus of bacteria determined in the present study, while the KGM diet elevated the faecal concentrations of bifidobacteria (week $0 v$. week $4, P=0 \cdot 038$ ), lactobacilli (week $0 v$. week $4, P=0.005$ ) and total bacteria (week 0 $v$. week $4, P=0.036$ ) (Table 4). The KGM diet also increased the relative proportion (\% of total bacteria) of faecal bifidobacteria and lactobacilli.

\section{Characteristics and dietary intake before and during the} study

The energy and macronutrients of volunteers between the placebo and the KGM groups were not significantly different (Table 5). The percentages of energy from proteins, carbohydrates and fat were approximately 15, 50 and $35 \%$, with low fibre intake, $<12 \mathrm{~g} / \mathrm{d}$ (excluding the KGM).

\section{Discussion}

This was the first study to show the role of KGM in reducing the risk of human colorectal cancer and suggest its possible mechanisms. The daily KGM supplement $(4.5 \mathrm{~g} / \mathrm{d})$ into a low-fibre Taiwanese diet beneficially reduced the faecal $\beta$-glucuronidase activity and secondary bile acid level. This soluble dietary fibre further ameliorated human faecal water-induced cytotoxicity and DNAdamaging effects towards Caco-2 cells, a model for colonic epithelium cells.

Instead of a high dose $(100 \mathrm{~g} / \mathrm{kg}$ diet $)$ of KGM used in previous animal studies ${ }^{(16,26)}$, results from the present study showed that daily supplementation of a relatively small amount of KGM was sufficient to reduce some toxin formation by reducing bacterial $\beta$-glucuronidase in the human colon. The reduced $\beta$-glucuronidase activity is likely to be due to the decreased clostridia population that produce a higher amount of $\beta$-glucuronidase than do lactobacteria or bifidobacteria ${ }^{(27)}$. In contrast, the present study did not observe effects of KGM on $\beta$-galactosidase activity. The modulatory role of non-digestible carbohydrates in faecal $\beta$-glucosidase activity has not been consistent among studies ${ }^{(28-32)}$. Similarly to effects of galacto-oligosaccharide, inulin and resistant $\operatorname{starch}^{(29-32)}$, the present study also observed an increase in faecal $\beta$-glucosidase activity with supplementation of KGM,

Table 3. DNA damage (denoted as tail moment) of Caco-2 cells treated with faecal water only or in combination with $\mathrm{H}_{2} \mathrm{O}_{2}$

(Mean values with their standard errors, $n 15$ )

\begin{tabular}{|c|c|c|c|c|c|c|c|c|}
\hline & \multicolumn{8}{|c|}{ Tail moment (DNA damage score) } \\
\hline & \multicolumn{4}{|c|}{ Placebo } & \multicolumn{4}{|c|}{ Konjac glucomannan } \\
\hline & \multicolumn{2}{|c|}{ Week 0} & \multicolumn{2}{|c|}{ Week 4} & \multicolumn{2}{|c|}{ Week 0} & \multicolumn{2}{|c|}{ Week 4} \\
\hline & Mean & SE & Mean & SE & Mean & SE & Mean & SE \\
\hline Faecal water & $12 \cdot 4$ & 0.6 & $13 \cdot 1^{*}$ & 0.6 & $13 \cdot 8$ & 0.5 & $11 \cdot 0^{\star \star \star}$ & 0.5 \\
\hline Faecal water $+75 \mu \mathrm{M}-\mathrm{H}_{2} \mathrm{O}_{2}$ & $49 \cdot 8$ & 1.7 & $50 \cdot 7$ & 1.6 & 54.0 & 0.7 & $44 \cdot 9^{\star \star \star}$ & 0.8 \\
\hline
\end{tabular}

Mean values were significantly different between week 4 and week 0 within a group (as analysed by paired Student's $t$ test): ${ }^{\star} P<0.05,{ }^{* \star \star} P<0.001$. 
Table 4. Changes in faecal bacterial population of adult volunteers supplemented with placebo or konjac glucomannan

(Mean values with their standard errors, $n$ 15)

\begin{tabular}{|c|c|c|c|c|c|c|c|c|}
\hline & \multicolumn{4}{|c|}{ Placebo } & \multicolumn{4}{|c|}{ Konjac glucomannan } \\
\hline & \multicolumn{2}{|c|}{ Week 0} & \multicolumn{2}{|c|}{ Week 4} & \multicolumn{2}{|c|}{ Week 0} & \multicolumn{2}{|c|}{ Week 4} \\
\hline & Mean & SE & Mean & SE & Mean & SE & Mean & SE \\
\hline \multicolumn{9}{|c|}{$\log _{10}$ counts/g wet faeces } \\
\hline Bifidobacteria & $9 \cdot 39$ & 0.04 & $9 \cdot 42$ & 0.04 & 9.24 & 0.09 & $9 \cdot 48^{\star}$ & 0.09 \\
\hline Lactobacilli & 8.86 & 0.08 & 8.94 & $0 \cdot 10$ & 8.63 & 0.07 & $8.90^{* *}$ & 0.08 \\
\hline Bacteroides & 8.90 & 0.12 & 8.94 & $0 \cdot 10$ & 8.68 & 0.09 & 8.76 & 0.09 \\
\hline Clostridia & $9 \cdot 32$ & 0.06 & 9.40 & 0.05 & $9 \cdot 33$ & 0.09 & $9 \cdot 24$ & 0.08 \\
\hline Total & $10 \cdot 17$ & 0.03 & $10 \cdot 21$ & 0.03 & $10 \cdot 17$ & 0.05 & $10 \cdot 24^{\star}$ & 0.05 \\
\hline \multicolumn{9}{|l|}{ Total bacteria (\%) } \\
\hline Bifidobacteria & $17 \cdot 3$ & 1.4 & $16 \cdot 6$ & 1.1 & $10 \cdot 3$ & 1.3 & $16 \cdot 7^{\star}$ & 1.8 \\
\hline Lactobacilli & 5.8 & 0.8 & $6 \cdot 4$ & 0.9 & $3 \cdot 1$ & 0.5 & $5 \cdot 3^{*}$ & 0.2 \\
\hline Bacteroides & 6.9 & 0.9 & $6 \cdot 1$ & 0.7 & $3 \cdot 7$ & 0.6 & $4 \cdot 1$ & 0.6 \\
\hline Clostridia & $16 \cdot 1$ & $2 \cdot 2$ & $16 \cdot 5$ & 1.5 & $16 \cdot 5$ & $2 \cdot 0$ & $11 \cdot 2^{*}$ & 1.3 \\
\hline
\end{tabular}

while fructo-oligosaccharide and guar gum hydrolysate (galactomannan polymer) do not exert this effect in humans ${ }^{(28,31)}$. In the present study, the KGM diet increased faecal $\beta$-glucosidase activity probably because faecal bacteria liberated $\beta$-glucosidase to decompose the glucomannan unit of KGM. Therefore, the present study suggests that KGM could reduce the formation of toxins that was mediated by the $\beta$-glucuronidase enzyme in the colon.

The present study investigated whether the KGM supplement would influence the level of carcinogenic bile acids by assessing the bile acid profile in the faecal water. The faecal water represents the portion of colonic content that directly contacts the colonic epithelium cells and is a good tool to assess the role of dietary intervention in colon carcinogenesis ${ }^{(20)}$. Previous studies have shown that hydrophilic bile acids are better tools for predicting colonic carcinogenesis than do total bile acids ${ }^{(33,34)}$.

Table 5. Daily dietary intake of adult volunteers in placebo or konjac glucomannan group during the present study*

(Mean values with their standard errors, $n$ 15)

\begin{tabular}{|c|c|c|c|c|}
\hline & \multicolumn{2}{|c|}{ Placebo } & \multicolumn{2}{|c|}{$\begin{array}{c}\text { Konjac } \\
\text { glucomannan }\end{array}$} \\
\hline & Mean & $\mathrm{SE}$ & Mean & SE \\
\hline Energy $(\mathrm{MJ} / \mathrm{d})$ & $7 \cdot 7$ & $0 \cdot 1$ & 7.9 & 0.1 \\
\hline \multicolumn{5}{|l|}{ Carbohydrates } \\
\hline$g / d$ & 233.2 & $3 \cdot 2$ & $240 \cdot 5$ & $5 \cdot 6$ \\
\hline$\%$ & $50 \cdot 4$ & 0.5 & $50 \cdot 4$ & 0.7 \\
\hline \multicolumn{5}{|l|}{ Protein } \\
\hline$g / d$ & 68.8 & $1 \cdot 1$ & $70 \cdot 4$ & $2 \cdot 3$ \\
\hline$\%$ & 14.9 & 0.2 & $14 \cdot 8$ & 0.3 \\
\hline \multicolumn{5}{|l|}{ Fat } \\
\hline$g / d$ & 71.7 & 1.8 & 73.9 & 1.7 \\
\hline$\%$ & 34.8 & 0.5 & 34.9 & 0.7 \\
\hline Dietary fibre† $(\mathrm{g} / \mathrm{d})$ & $11 \cdot 1$ & $0 \cdot 1$ & 11.3 & 0.2 \\
\hline
\end{tabular}

The present study therefore demonstrated the effect of KGM on the concentration and profile of bile acids in the faecal water. In contrast to the promoted effect of KGM on total bile acids in faeces ${ }^{(35)}$, KGM tended to decrease the total bile acids in the faecal water although without a statistical difference from the placebo. Particularly, KGM significantly decreased the secondary bile acid concentrations in the aqueous phase of faeces in the present study. The acidic faecal environment resulting from SCFA, the KGM fermentation products ${ }^{(13)}$, may facilitate the precipitation of hydrophilic deconjugated bile acids and inhibit their enzymatic formation from primary bile acids ${ }^{(36,37)}$. The reduced formation of secondary bile acids in faeces from the volunteers that consumed the KGM supplement suggests a protective role of KGM in human colonic carcinogenesis.

The present study agreed with previous studies that faecal water caused cell death and DNA damage in the human adenocarcinoma-derived cell lines ${ }^{(14,15,38,39)}$. KGM supplementation reduced the cytotoxicity of human faecal water towards Caco- 2 cells compared with the placebo in the present study, which agreed with a previous observation in mice ${ }^{(14,15)}$. The present study assessed the viability of the Caco-2 human adenocarcinoma cell by its ability to exclude trypan blue into the cells that indicates the integrity of the cell membrane. The greater cytoprotective effect of KGM may be related to its fermentation products, such as butyrate ${ }^{(40,41)}$. In addition, the KGM supplement reduced the production of secondary bile acids that was shown to cause damage of tight junctions ${ }^{(40)}$, which further contributed to the reduced cytotoxicity of faecal water towards Caco-2 cells. Therefore, we suggest that fermentation of KGM and the modulatory role of KGM on microbial metabolites contribute to the decreased faecal water cytotoxicty. 
In the present study, we assessed the acute effects of faecal water on DNA damage of Caco-2 cells. The KGM supplement in adult volunteers demonstrated a protective effect on faecal water-induced DNA damage, which was in agreement with our previous observation in mice ${ }^{(14,15)}$. The result was also supported by previous studies that demonstrated probiotics alone or fermentation of nondigestible oligosaccharides by probiotics ameliorated the genotoxicity of faecal water in human colonic adenocarcinoma cells ${ }^{(38,39)}$. The Caco-2 cells were further co-incubated with faecal water in combination with $\mathrm{H}_{2} \mathrm{O}_{2}$ in the present study to determine the protective effect of KGM against oxidative stress. The result indicated that the KGM supplement increased the defensive capacity of faecal water against $\mathrm{H}_{2} \mathrm{O}_{2}$, which may be mediated by free-radical-scavenging ability derived from fermentation of KGM by lactic acid bacteria ${ }^{(42)}$. In addition, butyrate produced from KGM fermentation ${ }^{(13)}$ may protect human colon cells from DNA damage as well ${ }^{(43,44)}$.

The present study confirmed the prebiotic role of KGM in healthy adults, i.e. increasing bifidobacteria and lactobacilli, which agreed with our previous observation in mice and in adult human subjects ${ }^{(12,45)}$. Although there is no direct experimental evidence for a cancer-suppressive role of probiotics in human subjects, there is a wealth of evidence emerging from laboratory studies ${ }^{(9)}$. We suggest that KGM supplementation may inhibit faecal toxicity partially by improving the human colonic microflora profile.

In conclusion, the present study suggests that a KGM supplement in healthy adults may beneficially exert chemopreventive effects for human colorectal cancer by a reduction of faecal water toxicity. These effects were likely to be associated with a reduction in $\beta$-glucuronidase activity and hydrophilic secondary bile acids and promotion of the colonic probiotic population.

\section{Acknowledgements}

The present study was supported by grant NSC 94-2320-B040-030, from the National Science Council, Taiwan. W.-T. W. conducted the human study and collected and analysed the samples. H.-L. C. designed and constructed the study and prepared the manuscript. H.-C. C. assisted in the human study and data collection. There is no conflict of interest in the present study.

\section{References}

1. Jemal A, Siegel R, Ward E, et al. (2008) Cancer statistics, 2008. CA Cancer J Clin 58, 71-96.

2. American Institute for Cancer Research (2007) Food, Nutrition, Physical Activity, and the Prevention of Cancer: a Global Perspective. Washington, DC: American Institute for Cancer Research.

3. Jenkins AL, Vuksan V \& Jenkins DA (2001) Fiber in the treatment of hyperlipidemia. In CRC Handbook of Dietary Fiber in Human Nutrition, pp. 423-430 [GA Spiller, editor]. New York: CRC Press.

4. Galloway DJ, Owen RW, Jarrett F, et al. (1986) Experimental colorectal cancer: the relationship of diet and faecal bile acid concentration to tumour induction. Br J Surg 73, 233-237.

5. Hughes R, Kurth MJ, McGilligan V, et al. (2008) Effect of colonic bacterial metabolites on Caco- 2 cell paracellular permeability in vitro. Nutr Cancer 60, 259-266.

6. Klinder A, Glei M \& Pool-Zobel B (2008) Prebiotics and reduction of risk of carcinogenesis: review of experimental and human data. In Handbook of Prebiotics, pp. 295-328 [G Gibson and M Roberfroid, editors]. Boca Raton, FL: CRC Press.

7. Kim YH, Park JW, Lee JY, et al. (2004) Sodium butyrate sensitizes TRAIL-mediated apoptosis by induction of transcription from the DR5 gene promoter through Sp1 sites in colon cancer cells. Carcinogenesis 25, 1813-1820.

8. Tong X, Yin L \& Giardina C (2004) Butyrate suppresses Cox2 activation in colon cancer cells through HDAC inhibition. Biochem Biophys Res Commun 317, 463-471.

9. Fotiadis CI, Stoidis CN, Spyropoulos BG, et al. (2008) Role of probiotics, prebiotics and synbiotics in chemoprevention for colorectal cancer. World J Gastroenterol 14, 6453-6457.

10. Kato K, Watanabe T \& Matsuda K (1970) Studies on the chemical structure of konjac mannan. Part II. Isolation and characterization of oligosaccharides from the partial acid hydrolyzate of mannan. Agric Biol Chem 34, 532-539.

11. Loening-Baucke V, Miele E \& Staiano A (2004) Fiber (glucomannan) is beneficial in the treatment of childhood constipation. Pediatrics 113, e259-e264.

12. Chen HL, Cheng HC, Wu WT, et al. (2008) Supplementation of konjac glucomannan into a low-fiber Chinese diet promoted bowel movement and improved colonic ecology in constipated adults - a placebo-controlled, diet-controlled trial. J Am Coll Nutr 27, 102-108.

13. Chen HL, Cheng HC, Liu YJ, et al. (2006) Konjac acts as a natural laxative by increasing stool bulk and improving colonic ecology in healthy adults. Nutrition 22, 1112-1119.

14. Yeh SL, Lin MS \& Chen HL (2007) Inhibitory effects of a soluble dietary fiber from Amorphophallus konjac on cytotoxicity and DNA damage induced by fecal water in Caco-2 cells. Planta Med 73, 1384-1388.

15. Yeh SL, Lin MS \& Chen HL (2010) Partial hydrolysis enhances the inhibitory effects of konjac glucomannan from Amorphophallus konjac C. Koch on DNA damage induced by fecal water in Caco-2 cells. Food Chem 119, 614-618.

16. Mizutani T \& Mitsuoka T (1983) Effect of konjac mannan on 1, 2-dimethylhydrazine-induced intestinal carcinogenesis in Fischer 344 rats. Cancer Lett 19, 1-6.

17. Department of Health (1998) Nutrient Composition Data Bank for Food of Taiwan Area. Taipei: Department of Health, Republic of China.

18. Pan WH, Chang YH, Chen JY, et al. (1999) Nutrition and health survey in Taiwan (NAHSIT) 1993-1996: dietary nutrient intakes assessed by 24-h recall. Nutr Sci J (Taiwan) 24 11-39.

19. Marteau P, Pochart P, Flourie B, et al. (1990) Effect of chronic ingestion of a fermented dairy product containing Lactobacillus acidophilus and Bifidobacterium bifidum on metabolic activities of the colonic flora in humans. Am J Clin Nutr 52, 685-688.

20. Rieger MA, Parlesak A, Pool-Zobel BL, et al. (1999) A diet high in fat and meat but low in dietary fibre increases the genotoxic potential of 'faecal water'. Carcinogenesis 20 , 2311-2316.

21. Czubayko F, Beumers B, Lammsfuss S, et al. (1991) A simplified micro-method for quantification of fecal excretion of 
neutral and acidic sterols for outpatient studies in humans. $J$ Lipid Res 32, 1861-1867.

22. Jansen GJ, Wildeboer-Velooet AC, Tonk RH, et al. (1999) Development and validation of an automated, microscopybased method for enumeration of groups of intestinal bacteria. J Microbiol Methods 37, 215-221.

23. Wang RF, Cao WW \& Cerniglia CE (1996) PCR detection and quantitation of predominant anaerobic bacteria in human and animal fecal samples. Appl Environ Microbiol 62, 1242-1247.

24. Manz W, Amann R, Ludwig W, et al. (1996) Application of a suite of 16S rRNA-specific oligonucleotide probes designed to investigate bacteria of the phylum cytophaga-flavobacter-bacteroides in the natural environment. Microbiology 142, 1097-1106.

25. Nagahama M, Nagayasu K, Kobayashi K, et al. (2002) Binding component of Clostridium perfringens iota-toxin induces endocytosis in Vero cells. Infect Immun 70, 1909-1914.

26. Mizutani T \& Mitsuoka T (1982) Effect of konjac mannan on spontaneous liver tumorigenesis and fecal flora in $\mathrm{C} 3 \mathrm{H} / \mathrm{He}$ male mice. Cancer Lett 17, 27-32.

27. Klinder A, Forster A, Caderni G, et al. (2004) Fecal water genotoxicity is predictive of tumor-preventive activities by inulin-like oligofructoses, probiotics (Lactobacillus rhamnosus and Bifidobacterium lactis), and their synbiotic combination. Nutr Cancer 49, 144-155.

28. Bouhnik Y, Flourie B, Riottot M, et al. (1996) Effects of fructo-oligosaccharides ingestion on fecal bifidobacteria and selected metabolic indexes of colon carcinogenesis in healthy humans. Nutr Cancer 26, 21-29.

29. Djouzi Z \& Andrieux C (1997) Compared effects of three oligosaccharides on metabolism of intestinal microflora in rats inoculated with a human faecal flora. Br J Nutr $\mathbf{7 8}$, 313-324.

30. Hylla S, Gostner A, Dusel G, et al. (1998) Effects of resistant starch on the colon in healthy volunteers: possible implications for cancer prevention. Am J Clin Nutr 67, 136-142.

31. Okubo T, Ishihara N, Takahashi $\mathrm{H}$, et al. (1994) Effects of partially hydrolyzed guar gum intake on human intestinal microflora and its metabolism. Biotech Biochem $\mathbf{5 8}$, 1364-1369.

32. Rowland IR, Rumney CJ, Coutts JT, et al. (1998) Effect of Bifidobacterium longum and inulin on gut bacterial metabolism and carcinogen-induced aberrant crypt foci in rats. Carcinogenesis 19, 281-285.

33. Rafter JJ, Eng VW, Furrer R, et al. (1986) Effects of calcium and $\mathrm{pH}$ on the mucosal damage produced by deoxycholic acid in the rat colon. Gut 27, 1320-1329.
34. Stadler J, Yeung KS, Furrer R, et al. (1988) Proliferative activity of rectal mucosa and soluble fecal bile acids in patients with normal colons and in patients with colonic polyps or cancer. Cancer Lett 38, 315-320.

35. Chen HL, Sheu WH, Tai TS, et al. (2003) Konjac supplement alleviated hypercholesterolemia and hyperglycemia in type 2 diabetic subjects - a randomized double-blind trial. J Am Coll Nutr 22, 36-42.

36. Fini A \& Roda A (1987) Chemical properties of bile acids. IV. Acidity constants of glycine-conjugated bile acids. J Lipid Res 28, 755-759.

37. Van Munster IP \& Nagengast FM (1993) The role of carbohydrate fermentation in colon cancer prevention. Scand $J$ Gastroenterol 200, 80-86.

38. Burns AJ \& Rowland IR (2004) Antigenotoxicity of probiotics and prebiotics on faecal water-induced DNA damage in human colon adenocarcinoma cells. Mutat Res $\mathbf{5 5 1}$, 233-243.

39. Oberreuther-Moschner DL, Jahreis G, Rechkemmer G, et al. (2004) Dietary intervention with the probiotics Lactobacillus acidophilus 145 and Bifidobacterium longum 913 modulates the potential of human faecal water to induce damage in HT29clone19A cells. Br J Nutr 91, 925-932.

40. Commane DM, Shortt CT, Silvi S, et al. (2005) Effects of fermentation products of pro- and prebiotics on trans-epithelial electrical resistance in an in vitro model of the colon. Nutr Cancer 51, 102-109.

41. Sauer J, Richter K \& Pool-Zobel B (2007) Physiological concentrations of butyrate favorably modulate genes of oxidative and metabolic stress in primary human colon cells. J Nutr Biochem 18, 736-745.

42. Wang $\mathrm{CH}$, Lai $\mathrm{P}$, Chen $\mathrm{ME}$, et al. (2008) Antioxidative capacity produced by Bifidobacterium- and Lactobacillus acidophilus-mediated fermentations of konjac glucomannan and glucomanan oligosaccharides. J Sci Food Agric 88, $1294-1300$

43. Abrahamse S, Pool-Zobel B \& Rechkemmer G (1999) Potential of short chain fatty acids to modulate the induction of DNA damage and changes in the intracellular calcium concentration by oxidative stress in isolated rat distal colon cells. Carcinogenesis 20, 629-634.

44. Ebert MN, Klinder A, Peters WH, et al. (2003) Expression of glutathione $S$-transferases (GSTs) in human colon cells and inducibility of GSTM2 by butyrate. Carcinogenesis $\mathbf{2 4}$, $1637-1644$.

45. Chen HL, Fan YH, Chen ME, et al. (2005) Unhydrolyzed and hydrolyzed konjac glucomannans modulated cecal and fecal microflora in Balb/c mice. Nutrition 21, 1059-1064. 